\title{
COMMENTARY
}

\section{Integral Ecology: An unexpected support for Ecological Economics by Pope Francis}

\author{
Marina Fischer-Kowalski *
}

\section{INTRODUCTION}

I was invited to give a talk at an international convention in the Vatican, organized by the Fondazione Vaticano Centesimo Anno Pro Pontifice in June 2019. It should serve the purpose of evaluating the impact of the papal encyclical issued in 2015 under the title Laudato Sí, coining the term integral ecology, of which I so far had not taken much notice.

The invitation took me by surprise: Why would an institution like the Vatican call for an conference to evaluate the impact of an encyclical, which is a papal letter sent to all bishops of the Roman Catholic Church, and invite responses from both its own "chapters" in the countries of the world (day one), and from international scientists irrespective of their religious background (day two) to give their feedback?

Before making a decision, I had to take a closer look at this encyclical. I found out it needed a long look (the document stretches across 186 pages), but my surprise deepened. The focus is clearly on the interlinkage between environmental destruction, global warming and social inequality as joint products of a particular model of progress. The following quotes from the encyclical make it clear.

We are faced not with two separate crises, one environmental and the other social, but rather with one complex crisis which is both social and environmental. Strategies for a solution demand an integrated approach to

\footnotetext{
* Institute of Social Ecology Vienna, University for Natural Resources and Life Sciences, Schottenfeldgasse 29, A-1070 Vienna, Austria; marina.fischer-kowalski@boku.ac.at

Copyright (C) Fischer-Kowalski 2020. Released under Creative Commons AttributionNonCommercial 4.0 International licence (CC BY-NC 4.0) by the author.

Published by Indian Society for Ecological Economics (INSEE), c/o Institute of Economic Growth, University Enclave, North Campus, Delhi 110007.
}

ISSN: 2581-6152 (print); 2581-6101 (web).

DOI: https://doi.org/10.37773/ees.v3i1.85 
combating poverty, restoring dignity to the excluded, and at the same time protecting nature. (Francis 2015, 104)

Further, it says that:

Human beings and material objects no longer extend a friendly hand to one another; the relationship has become confrontational. This has made it easy to accept the idea of infinite or unlimited growth, which proves so attractive to economists, financiers and experts in technology. It is based on the lie that there is an infinite supply of the earth's goods. [...] The effects of imposing this model on reality as a whole, human and social, are seen in the deterioration of the environment, but this is just one sign of a reductionism which affects every aspect of human and social life. We have to accept that technological products are not neutral, for they create a framework which ends up conditioning lifestyles and shaping social possibilities along the lines dictated by the interests of certain powerful groups. Decisions which may seem purely instrumental are in reality decisions about the kind of society we want to build. (Francis 2015, 79-80)

If that is not enough, it goes on to say:

It is not enough to balance, in the medium term, the protection of nature with financial gain, or the preservation of the environment with progress. Halfway measures simply delay the inevitable disaster. Put simply, it is a matter of redefining our notion of progress. (Francis 2015, 142)

I was impressed. In these quotes, some fundamentally critical elements meet: the intertwining of environmental destruction and social inequality, a challenge to the idea of permanent economic growth, and a view on technology not as a solution, but as a means of imposing a mode of living in the interest of some powerful groups. Mind who is speaking: the spiritual head of a religious organization comprising one third of humanity.

Finally:

A true ecological approach always becomes a social approach; it must integrate questions of justice in debates on the environment, so as to hear both the cry of the earth and the cry of the poor. (Francis 2015, 35; emphasis as in the original)

This all sounded close to what I pursue in my professional life: a fundamental critique of the prevailing model of development. So I took my decision and agreed to speak on day two of this convention, expecting my concerns, and my data, to be in good company. 


\section{HOW THE CONFERENCE OF THE FONDATIONE VATICANO EVOLVED}

The introductory session on this day, though, first reconfirmed my prejudice about the power of hierarchy, but also the lack of mutual support in this institution: Cardinal P K A Turcson elaborated on a number of things, lacking a strong emphasis on the issues of the encyclical. He took much more time than assigned to him and thus eliminated the chance for a public debate among the 400 participants for the rest of the day.

Janez Potocnik, Chair of the UN Environment International Resource Panel, then gave a perfectly disciplined keynote, backing up environmental alarms of the Encyclical with current data on the relentless rise of global demand for natural resources (tripling from 1970-2017); the resource extraction and processing phase is shown to be responsible for 90 per cent of biodiversity loss and water stress, and 50 per cent of global climate change impacts. Measured in material footprints, high-income countries are by far the largest consumers per capita and increasing their import dependence.

The next keynote came from Stefano Manservisi, Director General for International Cooperation and Development of the European Union, on the current status of the 2030 agenda, compared to 1980. A compact assembly of good news and bad news, such as: poverty rate has declined, from 40 to 10 per cent (but still 800 mio people concerned; and 50 per cent of them live in middle-income countries); inequality is on the rise: the $1 \%$ richest has seen double the gains of the bottom 50 per cent. And this trend is all over the world but particularly acute in advanced economies. The extreme case is the United States, where the top 1 per cent now holds 42.5 per cent of the national wealth - much more than in any other OECD country.

He emphasised the efforts from the part of EU to strengthen partnerships with others working on the Agenda 2030 in developing countries. Thus, for instance, whether we use the term "integral ecology" or the EU's "sustainable development", it is clear that there is a great convergence between the objectives of the Holy See and of the EU.

The SDGs are not only about convergence but also finding a new (and unknown) sustainable and inclusive development model where all, rich and poor, need to transform and to get closer. The major trends of our times technology, climate, migration, inequality, poverty - force us to rebuild a collective and cooperative action at international level. (Manservisi 2019, 12)

Jeffrey Sachs, Professor and Director of the Centre for Sustainable Development, Columbia University, took his turn into the history of 
philosophy, comparing the conception of "economy" between Aristotle (whom he views as a forebearer of the Church's social teachings) and Hobbes/Adam Smith, as moulders of capitalism. Never could an economy built upon the premise of maximizing individual utility of each transaction properly take care of the common good. He welcomes the fundamental critique of the current economy as he finds it in the Encyclical.

In the ensuing panel discussion on "The many obstacles obstructing the path to an integral ecology", I had my own chance to show, on the one hand, that in some ways the economy responds reasonably: disinvestment in fossil fuel mining companies spreads, and investment in renewables (that still amount to less than 5 per cent of global primary energy supply) rises. On the other hand, while the industrial cheerleaders $(20$ per cent of the world population) reduced their fossil fuel use in the last 20 years by a few percent, the emerging economies (who increasingly produce and deliver the commodities the cheerleaders use), more than doubled it (Schaffartzik and Fischer-Kowalski 2018). Thus, globally, fossil fuel use is still on the rise (Krausmann et al. 2019).

\section{DID THE PAPAL ENCYCLICAL LAUDATO SÍ MAKE A DIFFERENCE?}

In effect: If we use numbers to document the Encyclical's impact, there is little to be found. But maybe, if we look for social movements and changed mindsets, something seems to be going on. When latent changes in mindsets turn public, they can trigger mass action as we now see with Fridays for Future movement. We face a really fundamental challenge, heading, if successfully resolved, for an entirely new approach to nature, economics and social distribution. The emergence of such a new approach presupposes a gradual and persistent change in mindsets across the globe, and across various segments of the world population. And this is where Laudato Si may have already had some impact, and may continue to exert its influence, at a grass roots level.

One could not but agree with the chairwoman Anna Maria Tarantola (Professor in Economics and Banker) when she observed at the end of the convention:

Laudato Si' provides a prophetic voice which calls attention to the negative consequences - ecological, social, economic and political - of the present model of development and underline the urgency of systematic and concerted efforts aimed at an Economy with a human face. [...] The dominant technocratic paradigm is part of a spiritual disorder, with the self at the centre of reality and will and desire dominating both society and nature. Connected with this are not 
just selfishness and greed, but also the externalisation of ecological and social costs. The problem is that our prevailing economic models privatise profits and socialise costs. (Tarantola and Pabst 2019,2)

Among the propositions for practical action are: a four-day workweek with the same pay; fair, free public transport; the need to modify companies' strategies, governance and organization in order to take care of the needs of all the stakeholders, not only those of shareholders.

So, quite obviously, not only the papal encyclical but also the follow-up convention confirmed the impression that the Catholic Church has put forth a fundamental critique of the dominant world economy, based on two arguments: its destructive impact on the natural environment ("Our Common Home"), its threat to the world climate in particular, and its production of massive social inequality. For ecological economists, nothing about this is particularly new.

What is new though, I think, is that an institution accepted as religious and possibly moral authority by roughly one third of the world population, joins in on that interpretation, and sanctifies it. These views explicitly undermine the claims made by the deniers of human-driven climate change, underscore a critical situation crying for urgent change, and do not just appeal to hope and support from the Mighty, but ask for action across the globe. Such action, on the level of governments, cities, industry, local communities, and individual households, has started here and there; on the international level, the bottom-up process leading to the agreement on Sustainable Development Goals also is a symptom for new ways. All this, I believe, has not yet reached a tipping point after which the process becomes selfreinforcing, and turns the numbers. We can also see many processes tipping the other way, towards increased hostility between social groups, aggressive nationalism, and denial of the ecological challenge. So our world is in suspense, possibly tipping in either direction; lucky those who share a firm belief, and get it reinforced by a papal encyclical.

\section{REFERENCES}

Francis, Pope. 2015. Laudato Sí: On Care for Our Common Home. Encyclical Letter. Vatican City: Our Sunday Visitor. Accessed online at http://w2.vatican.va/content/dam/francesco/pdf/encyclicals/documents/papafrancesco 20150524 enciclica-laudato-si en.pdf on 19 December 2019.

Krausmann, F., C. Lauk, W. Haas, and D. Wiedenhofer. 2018. "From Resource Extraction to Outflows of Wastes and Emissions: The Socioeconomic Metabolism of the Global Economy, 1900-2015," Global Environmental Change 52 (September): 131-40. https://doi.org/10.1016/i.gloenvcha.2018.07.003. 
Manservisi, Stefano. 2019. 'Status of the 2030 Agenda'. Keynote speech at the Catholic Social Teaching from Inception to the Digital Age: how to live the Laudato Si' Convention 6-8 June 2019 New Synod Hall, Vatican City. Accessed online at http://www.centesimusannus.org/wp-content/uploads/2019/06/1.Paper-by-Dr.-MANSERVISI.pdf on 19 December 2019.

Schaffartzik A. and M. Fischer-Kowalski. 2018. "Latecomers to the fossil energy transition, frontrunners for change? The Relevance of the Energy 'Underdogs' for Sustainability Transformations," Sustainability 10.

https://doi.org/10.3390/su10082650

Tarantola, Anna Maria and Adrian Pabst. 2019. "Summary of 2019 International Convention". Catholic Social Teaching from Inception to the Digital Age: how to live the Laudato Si' Convention 6-8 June 2019, New Synod Hall, Vatican City. Accessed online at http://www.centesimusannus.org/wpcontent/uploads/2019/07/Summary-of-2019-FCAPP-InternationalConvention.pdf on 19 December 2019 